\title{
Toxicity of Ammonia to Benthic Amphipod Grandidierella bonnieroides: Potential as Confounding Factor in Sediment Bioasssy
}

\author{
Dwi Hindarti1,2*, Zainal Arifin ${ }^{1}$, Tri Prartono², Etty Riani², and Harpasis S. Sanusi ${ }^{2}$ \\ ${ }^{1}$ Research Centre for Oceanography, Indonesian Institute of Sciences, \\ Jl. Pasir Putih I, Ancol Timur, Jakarta 14430 \\ ${ }^{2}$ Faculty of Fisheries and Marine Sciences, Bogor Agricultural University, \\ Jl. Agatis, Dramaga Campus, Bogor Indonesia 16680 \\ Email: hindartidwi@gmail.com
}

\begin{abstract}
Toxicity of ammonia was evaluated using amphipod Grandidierella bonnieroides to describe its role as confounding factor in sediment quality assessment. Ammonia is a toxic compound that is found naturally in seawater and sediment. High ammonia content in the pore water sediment can be potentially toxic to benthic biota, so that it will interfere with the results of sediment toxicity tests. Laboratory production amphipod was used in this ammonia toxicity test. Water-only toxicity tests was conducted to produce new toxicity data of ammonia, and is expressed as LC50, LOEC and NOEC for benthic amphipod G.bonnieroides. The study resulted the 96- $h$ median lethal concentration (LC50) of ammonia for G. bonnioerides was $65.5 \mathrm{mg} . \mathrm{L}^{-1}$. While the value LOEC (Iow observed effect concentration) is $56 \mathrm{mg} \cdot \mathrm{L}^{-1}$ and NOEC value (no observed effect concentration) was $32 \mathrm{mg} . \mathrm{L}^{-1}$. This shows that ammonia has a relatively low toxicity to amphipod and ammonia does not act as a confounding factor in the sediment toxicity test, because the ammonia content in sediment does not pose any significant effect on amphipod survival. It can be concluded that the amphipod has a potential useful as test organism in sediment bioassay for assessing the quality of marine sediment. Moreover, the high dependence of total ammonia toxicity indicates that it is necessary to measure the total ammonia and $\mathrm{pH}$ of the medium when testing environmental samples.
\end{abstract}

Keywords: ammonia, amphipod, toxicity, confounding factor, bioasssay

\begin{abstract}
Abstrak
Toksisitas ammonia terhadap amphipod bentik Grandidierella bonnieroides : Potensi sebagai faktor pengganggu dalam bioassay sedimen
\end{abstract}

Toksisitas ammonia dievaluasi menggunakan amphipod Grandidierella bonnieroides untuk menggambarkan perannya sebagai faktor pengganggu dalam penilaian kualitas sedimen. Amonia merupakan senyawa beracun yang ditemukan secara alami dalam air laut dan sedimen. Kandungan amonia yang tinggi dalam air pori sedimen dapat berpotensi racun bagi biota bentik, sehingga akan mengganggu hasil uji toksisitas sedimen. Amphipod hasil produksi laboratorium digunakan dalam uji amonia. Uji toksisitas dilakukan untuk menghasilkan data toksisitas baru ammonia, dan dinyatakan sebagai LC50, LOEC dan NOEC untuk G.bonnieroides amphipod bentik. Studi ini menghasilkan nilai konsentrasi median letal 96-jam (LC50) ammonia untuk G. bonnioerides adalah 65.5 mg. L-1. Sedangkan nilai LOEC (konsentrasi terendah yang menyebabkan dampak secara signifikan) adalah 56 mg. $L^{-1}$ dan nilai NOEC (konsentrasi tertinggi yang tidah menyebabkan dampak secara signifikan) $32 \mathrm{mg} . \mathrm{L}^{-1}$. Hal ini menunjukkan bahwa ammonia memiliki toksisitas relatif rendah untuk amphipod dan ammonia tidak bertindak sebagai pengganggu dalam untuk uji toksisitas sedimen, karena kandungan ammonia dalam sedimen tidak menimbulkan pengaruh yang nyata pada survival amphipod. Dapat disimpulkan bahwa amphipod memiliki potensi sebagai biota uji dalam sedimen bioassay untuk menilai kualitas sedimen laut. Selain itu, terdapat ketergantungan yang tinggi toksisitas amoniak terhadap $\mathrm{pH}$, sehingga perlu untuk memantau total amonia dan pH saat melakukan pengujian sampel lingkungan.

Kata kunci : ammonia, amphipod, toksisitas, faktor pengganggu, bioassay 


\section{Introduction}

It is important to identify the contaminant that is responsible for sediment toxicity in the sediment quality assessment studies. The biological fraction of contaminant available for benthic organisms was reported to be the most of concern and it has been highly correlated with the concentrations of contaminant in interstitial (pore) water (Swartz et al., 1986; Burgess et al., 1993; Whiteman et al., 1996).These studies have confirmed that biological effects based on pore-water chemical concentrations are similar to concentration-response relationship resulted from water-only toxicity test with the same chemicals. Several studies revealed ammonia has been responsible for the toxicity of contaminant in sediment (Boardman et al., 2004; Ingersoll et al., 2015). High concentrations of ammonia in sediment pore water may have contributed to the observed toxicity. For these reason, misinterpretation of the sediment assessment studies result will be a critical to the development of successful remedial strategies.

Ammonia is a relatively toxic compound produced in natural waters and sediments by heterotrophic bacteria as a primary by-product of the decomposition of organic matter (Russo 1985) and become a potentially highly toxic occuring constituent of sediment pore waters for aquatic organisms (Burgess et al., 1993; Whiteman et al., 1996). Anthropogenic sources included waste water effluents and terrestrial runoff can significantly increase ammonia concentrations in coastal environments. Since ammonia is highly soluble and readyly released from sediment during resuspensions process, it is recycled via the pore water to the water column and epibenthic/benthic organisms can be exposed to high concentrations of ammonia in solid-phase and elutriate toxicity test (Alessandra et al., 2003) so that ammonia may affect outcomes of contaminant toxicity test (Mehler et al., 2010; Batley and Simpson 2009). It is, therefore, needed to determine the sensitivity limit to ammonia in the methods used in sediment toxicity assessment.

In aquatic environments, ammonia is in equilibrium between two chemical species: unionized ammonia $\left(\mathrm{NH}_{3}\right)$ and ammonium ion $\left(\mathrm{NH}_{4}^{+}\right)$ (Russo, 1985). Total ammonia is the sum of $\mathrm{NH} 3$ and $\mathrm{NH} 4+$, and it is total ammonia that is measured analytically in aqueous solution. The neutral, unionized form is highly toxic to fish and other aquatic life because of its ability to diffuse readily across phospholipid cell membranes; ammonium effects are less marked (US EPA, 2001a; Boardman et al., 2004). Unionized ammonia is the most toxic form, although there is evidence that the ammonium ion also contributes to toxicity (USEPA, 1999). It has been recommended a water quality criteria for unionized ammonia value of $0.035 \mathrm{mg} . \mathrm{L}^{-1}$ for salt water acute effects (US EPA,1999), a guideline for ammonia in sediment pore waters, a guideline trigger value of $3.9 \mathrm{mg}$ total $\mathrm{NH3}-\mathrm{N} /$ Lbased on species sensitivity disribution (Batley and Simpson, 2009). The Australian and New Zealand currently revised guideline of $4 \mathrm{mg}$ total $\mathrm{NH3}-\mathrm{N} / \mathrm{L}$ as conservative value after recommended previously as a guideline trigger value (Batley and Simpson, 2009).

The toxicity of ammonia to benthic organisms, especially amphipods, has been evaluated in 96-h water-only exposures (Kohn et al., 1994; SchubauerBerigan et al., 1995; Alessandra et al., 2003; Boardman et al., 2004; Lee et al., 2005a). Recent study using mussels demonstrated that the acute sensitivity to ammonia was not influenced by the presence of substrate in 4-d laboratory toxicity tests (Wang et al., 2011). This indicated that results of the water-only toxicity test can be used to predict the toxicity of the sediment pore water toxicity. High levels of ammonia in sediment toxicity tests can potentially confound test results and a significant potential for ammonia induced interference has been reported in the 10-d test using estuarine amphipod (Leptocheirus plumulosus) but not for the 28-d tests due to rapid dissipation of ammonia via renewal of overlying water (Moore et al., 1997). Toxicity of ammonia was found to be highly $\mathrm{pH}$ dependent (Van Sprang and Janssen 1997). Increased toxicity was observed at higher $\mathrm{pH}$ levels, whereas reduced toxicity was found lower $\mathrm{pH}$ levels.

Amphipods have been used in the assessment of sediment quality studies due to their sensitivity, abundant, ease of handling and widely distribution (Angel et al., 2010, US EPA 2001a). Among the amphipods, Grandidierella japonica was commonly used as standard test organism in other countries (Lee et al., 2005, USEPA, 2001b). However, available information was limited on the sensitivity of benthic amphipod Grandidierella bonnieroides to sediment particle size (Hindarti et al., 2015). Then this study was aimed essentially to evaluate the effect of ammonia on mortality of benthic amphipod Grandidierella bonnieroides to elucidate the role the environmental factor in sediment assessment studies. Also, it is required to conclude whether or not the amphipods is suitable as test organism for sediment bioassay in terms of their sensitivity to ammonia contamination. 


\section{Materials and Methods}

Benthic indigenous amphipod Grandidierella bonnieroides Stephenson 1948 was collected from the upper layer of sediment from the low intertidal zone located in Kramat Kebo estuary (5098'33" N, 106070'33" E), Banten, Indonesia, using a stainlesssteel spoon. Sediment containing amphipods were transferred to plastic container containing a 2- to 3$\mathrm{cm}$ layer of sediment and seawater. They were transported to the laboratory in low temperature by given ice pack into container to prevent overheating. In the laboratory, amphipods were sieved out of the sediment and sorted based on size, > 3,5 $\mathrm{mm}$ and $\leq$ $3,5 \mathrm{~mm}$ lengths (Hindarti et al., 2015). Amphipod used in this test was obtained from larvae production of gravid females. Seven days larvae (neonates) of amphipod or approximately 3-5 mm length are ready for used for bioassay. To determine the 7 days old is by the time they release from the pouch.

Acute toxicity test of ammonia was conducted based on procedures of ASTM (2006) with slight modification to tropical temperature. UV-sterilized and filtered natural seawater at salinity 30 ppt was used as a dilution water in the toxicity tests and a negative control factor. Stock solution of total ammonia was prepared by dissolving (NH4)2SO4 (EMERCK) in the treated natural seawater at $25^{\circ} \mathrm{C}$ and salinity 30 ppt. Five nominal ammonia concentrations were prepared for acute toxicity test, the values were $18,32,56,100$, and $180 \mathrm{mg} . \mathrm{L}^{-1}$ total ammonia( $\left.\mathrm{NH}_{4}^{+}+\mathrm{NH} 3\right)$, and were exposed to the amphipods for 96-h. Amphipods were also exposed to cadmium as a reference toxicant and it was conducted concurrently to the test.

The tests was conducted in four replicates and 20 individuals of amphipod were allocated to each treatments. Observation of dead individual and water quality of the test media were made in the daily basis. No test water renewal was made for all of the tests. The $\mathrm{pH}$ was measured with a Model 290 Orion meter, dissolve oxygen and temperature were measured with a YSI model 58 DO meter.

The acceptability of test results was fixed a percentage of amphipod survival $\geq 90 \%$ in all negative control, and only if the LC50 with the reference toxicant fell within the accepable range (ASTM, 2006). All calculations originate from nominal ammonia concentrations and expressed as total ammonia nitrogen (i.e. mg N/L). Median lethal concentrations (LC50s) with 95\% confidence limits were calculated by the Trimmed Spearman-Karber statistical method (Hamilton et al., 1977) and were based on total ammonia and unionized ammonia. The fraction of unionized ammonia was calculated using ammonia calculator (SVL Analytical, 2010) at differing values of $\mathrm{pH}$ and temperature, and known concentration of total ammonia. After tests were completed, survival data was analyzed to determine the LC50,NOEC, and LOEC by analysis of variance (ANOVA) and Dunnett's one-tailed t-test on arcsine square-root transformed data using TOXSTAT software.

\section{Results and Discussion}

A common practice during bioassay, most experiments use a reference toxicant as a positive control in order to have a compatibility of all across experiment conditions and to determine the level of sensitivity of biota used as test biota. Cadmium (Cd) was used in the present study as a reference toxicant due to its highly toxicity and stability along the duration of the test (Gorbi et al., 2012). The LC50 value calculated from this data was $0.70 \mathrm{mg} . \mathrm{L}$ 1 , the NOEC and LOEC value were 0.32 mg. L-1 and $0.56 \mathrm{mg} . \mathrm{L}^{-1}$, respectively. The toxicity of $\mathrm{Cd}$ to amphipods has been extensively tested (Lee et al., 2005b; Kohn et al., 1994; DeWitt et al., 1989). The LC50 value of Cd for $\mathrm{G}$. bonnieroides in the present study toxicity was within the range of the LC50s value for most of the amphipods tested (Table 1), which varied in the range from $0.36 \mathrm{mg} . \mathrm{L}^{-1}$ for Leptocheirus plumolatus and 2.9 mg. $\mathrm{L}^{-1}$ for Ampelisca abdita. Therefore, the amphipod of $G$. bonnieroideswas as sensitive as the standard testspecies used in other countries and proves to be a suitable species to use in estuarine acute toxicity testing showing high potential to identify both overlaying water contamination and sediment degradation.

A wide range of ammonia concentrations was tested to cover the effects on mortality of amphipods. The water-only test of ammonia with G. bonnieroides had acceptable control survival and exhibited a conccentration-dependent increase in the toxicity of ammonia (Figure 1). Throughout the experiment period, control showed $97.5 \pm 5 \%$ of amphipod survival. The first significant effect onmortality (LOEC) was found at an exposure to 56 mg.L-1 total ammonia and the concentration of ammonia that have no a significant effect on mortality was $32 \mathrm{mg} . \mathrm{L}^{-1}$ (Figure 1). The effects increased markedly at higher exposure levels and the median lethal concentration (LC50-96h) value of ammonia calculable from this data was $65.49 \mathrm{mg} . \mathrm{L}^{-1}$ 
Table 1.The 96-h LC50 values of cadmium for various marine and estuarine amphipods

\begin{tabular}{lcc}
\hline \multicolumn{1}{c}{ Species } & 96-h LC50 (mg.L-1) & Reference \\
\hline Ampelisca abdita & 2.9 & USEPA (2001a) \\
Grandidierella japonica & 1.17 & USEPA (2001b) \\
Eohaustorius estuarius & 1.47 & Lee et al., (2005a) \\
Leptocheirus plumolatus & 2.4 & ASTM (2006) \\
& 0.36 & USEPA (2001a) \\
Repoxynius abronius & 0.53 & Kohn et al., (1994) \\
& 0.76 & DeWitt et al., (1989) \\
Monocorophium achersicum & $0.75,1.1$ & ASTM (2006) \\
& $0.7-1.4$ & Lee et al., (2005b)
\end{tabular}

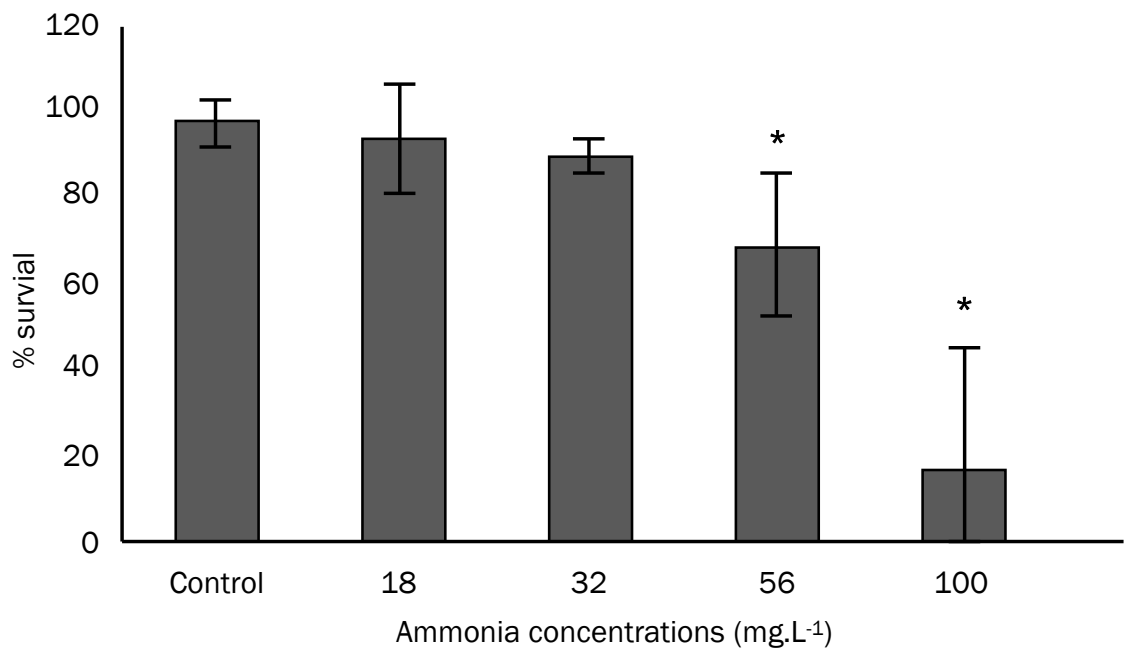

Figure 1. Survival of amphipods at $96-\mathrm{h}$ of ammonia exposure. *statistical significant at $p<0.05$

as total ammonia $\left(\mathrm{NH}^{+}+\mathrm{NH} 3\right)$. Toxicity test using amphipods generally conducted in order to clarify the role of ammonia as confounding factor in sediment quality assessment studies. The 96-h LC50 of total ammonia for G. bonnieroides in the present study showed that G. bonnieroides was relatively tolerable to ammonia in water-only exposure when compare to Paracentrosus lividus (5.7 mg.L-1) (Alessandra et al., 2003), Ampelisca abdita (50 mg. L-1) (US EPA, 1994) and Leptocheirus plumulosus (44-89 mg.L-1) (Moore et al., 1997), but less tolerance when compare to Repoxynius abronius (79 mg.L-1) (US EPA, 1994), Eohaustorius estuaries (126 mg.t-1 ) (Kohn et al., 1994) and G. japonica (141 mg.L-1 148 mg.L-1) (Lee et al., 2005a; US EPA, 1994) which were used as standard test organism in sediment bioassay in the USA and other countries. Ammonia concentrations in sediment porewater are commonly thousands of times higher than in overlying water; therefore, ammonia can exert severe toxicity in some organically polluted sediments (Ferretti et al., 2000). The effect of contaminant in sediment pore water can be predicted by water-only toxicity data for the same contaminant both for freshwater and seawater species (Newton and Bartsch, 2007; Whiteman et al., 1996; Burgess et al, 1993).Hence, the bioavailability of ammonia to benthic macroinvertabrates can indeed be accurately related to sediment pore water contentrations. If the pore water ammonia concentrationsis in the range of the water-only LC50 for the species of concern, the ammonia could be presumed as possibly being responsible for observed toxicity. Therefore, relatively high tolerance of $G$. bonnieroidesto ammonia can be useful as test species for sediment bioassay.

The relative ammonia toxicity (expressed as a total ammonia) for $G$. bonnieroides increased as $\mathrm{pH}$ increases. The first significantly $(P<0.05)$ increase in $\mathrm{pH}$ value was found in the $48 \mathrm{~h}$ of exposure and afterwards (Figure 2). At the end of the test (96-h) the $\mathrm{pH}$ value was significantly increased $(P<0.05)$ compared to the control at the beginning of the test, and then increases in mortality of the amphipods. 
This is due to differences in the relative toxicity of unionized ammonia (NH3) versus ammonium ion $\left(\mathrm{NH}^{+}\right)$as explained by Schubauer-Berigan et al. (1995) that at low pH values the ionized ammonium ion predominates, and as $\mathrm{pH}$ increases the equilibrium shiifts toward the more toxic unionized ammonia. Schubauer-Berigan et al. (1995) found that over the $\mathrm{pH}$ range of 6.5 to 8.6 the sensitivity of the benthic macroinvertebrates to total ammonia increased by 4-40 order of magnitudes.

Un-ionized ammonia is the form of ammonia that is toxic to aquatic life due to its characteristic that can most readily reach entry to aquatic organism. The un-ionized ammonia calculated as a function of $\mathrm{pH}$, temperature and total ammonia

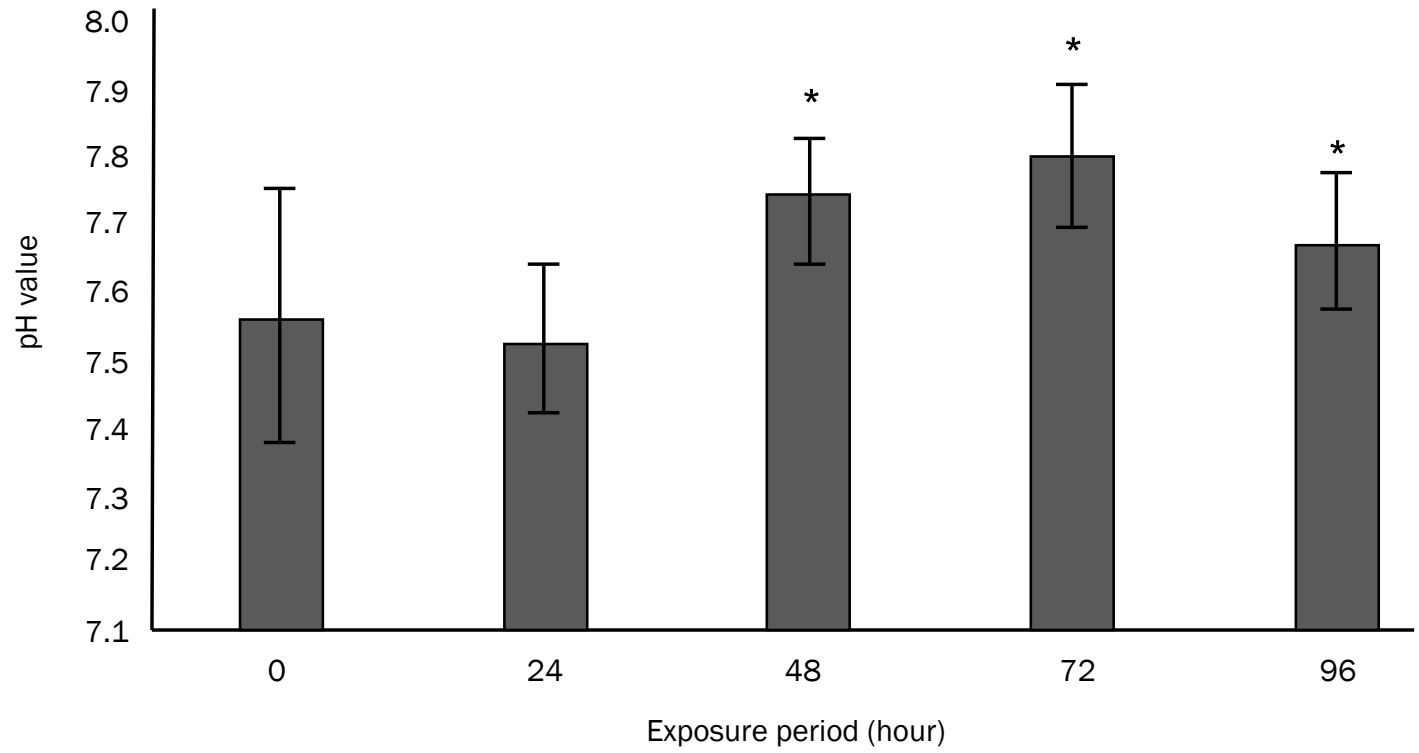

Figure 2. Changes in $\mathrm{pH}$ value during the test. * statistical significant at $p<0.05$

Table 2. Summary of of toxicity data for 96-h water-only test conducted with G. bonnieroides. Ammonia concentrations are indicated as nominal total ammonia ( $\mathrm{mg} \mathrm{N} / \mathrm{L}$ )

\begin{tabular}{ccccccc}
\hline Chemical & \multirow{2}{*}{ NOEC } & \multirow{2}{*}{ LOEC } & \multirow{2}{*}{ LC50 } & \multicolumn{2}{c}{$96 \mathrm{~h}-\mathrm{LC50} 95 \% \mathrm{Cl}$} \\
\cline { 5 - 7 } & & & 56 & 65.5 & 59.46 & $\mathrm{UL}$ \\
\hline Ammonia (mg N/L) & 32 & 1.039 & 2.760 & 1.70 & 1.574 & 1.843 \\
\hline Unionized ammonia (mg.L-1) & &
\end{tabular}

Cl - Confidence Interval; LL - Lower limit; UL - Upper limit

Table 3. Summary of toxicity data for 96-h water-only ammonia toxicity test conducted with G. bonnieroides Stephenson 48. Ammonia concentrations are indicated as total ammonia (nominal).

\begin{tabular}{|c|c|c|c|c|}
\hline Ammonia conc. (mg. $\left.\mathrm{L}^{-1}\right)$ & $\mathrm{pH}$ & Temperature $\left({ }^{\circ} \mathrm{C}\right)$ & Unionized conc. (mg.L-1) & Mortality (\%) \\
\hline Control & $\begin{array}{c}7.67 \\
(7.33-7.88)\end{array}$ & $\begin{array}{c}25.06 \\
(24.1-26.2)\end{array}$ & 0 & $\begin{array}{c}2.5 \\
(0-10)\end{array}$ \\
\hline 18 & $\begin{array}{c}7.74 \\
(7.61-7.88)\end{array}$ & $\begin{array}{c}25.36 \\
(24.4-26.6)\end{array}$ & 0.535 & $\begin{array}{c}6.3 \\
(0-25)\end{array}$ \\
\hline 32 & $\begin{array}{c}7.72 \\
(7.5-7.87)\end{array}$ & $\begin{array}{c}25.76 \\
(24.7-26.7)\end{array}$ & 1.039 & $\begin{array}{c}10 \\
(5-15)\end{array}$ \\
\hline 56 & $\begin{array}{c}7.70 \\
(7.59-7.83)\end{array}$ & $\begin{array}{c}25.86 \\
(24.7-27.1)\end{array}$ & 1.421 & $\begin{array}{c}31.3 \\
(15-45)\end{array}$ \\
\hline 100 & $\begin{array}{c}7.62 \\
(7.42-7.73\end{array}$ & $\begin{array}{c}25.7 \\
(24.4-27.2)\end{array}$ & 2.542 & $\begin{array}{c}83.8 \\
(40-100)\end{array}$ \\
\hline 180 & $\begin{array}{c}7.50 \\
(7.32-7.62)\end{array}$ & $\begin{array}{c}26.18 \\
(25.2-27.1)\end{array}$ & 3.61 & 100 \\
\hline
\end{tabular}


concentration was presented in Table 3. The LC50 value of unionized ammonia for $\mathrm{G}$. bonnieroides was $1.70 \mathrm{mg} \mathrm{NH3/L}$ (Table 2) and was lower than the value of 3.5 mg. $\mathrm{L}^{-1}$ found forG. japonica(Lee et al., 2005), was higher than the value of $0.43 \mathrm{mg} . \mathrm{L}^{-1}$ found for Allorchestes compressa (Adams and Strauber, 2007). The LC50 value of un-ionized for G. bonnieroides was higher than the water quality criteria for un-ionized ammonium set by US EPA (1999), indicating the amphipod used in this study was tolerant to un-ionized ammonia exposure. The sensitivity of $G$. bonnieroides to un-ionized exposure was comparable to other standard tests species used in other countries indicating the benefecial used of the species in the sediment bioassay.

\section{Conclusion}

Survival of $G$. bonnieroides significantly responded to ammonia concentrations and the toxicity of ammonia was relaitively low to the amphipods. The sensitivity of G. bonnieroides was comparable to other standard amphipod test species, and Itindicates that the interference of ammonia on the sediment toxicity results is relatively less important. Therefor, this study suggest that the amphipod has a potential useful as test organism for sediment bioassay in the marine sediment assessment. Moreover, the high dependence of total ammonia toxicity indicates that it is necessary to measure total ammonia concentrations and $\mathrm{pH}$ of the medium accurately when testing environmental samples.

\section{Acknowledgement}

This work was funded by the Indonesian Government through the DIPA of the Research Centre for Oceanography, Indonesian Institute of Sciences. We are grateful to Toro, Suratno, Triyoni Purbonegoro, Rachma Puspitasari, and Eston Matondang who helped in the technical works.

\section{References}

Adams, M.S. \& J.L. Stauber. 2007. Toxicity of Ammonia with Varying Salinity to the Amphipod Allorchestes compressa. CSIRO Land and Water Science Report 10/07,Lucas Heights, NSW, Australia, 31p.

Alessandra, A.N., P. Marco, L. Chiara, \& V. G. Annamaria. 2003. Ammonia as confounding factor in toxicity tests with the sea urchin Paracentrotus lividus (Lmk). Toxicol. Environ.
Chem. 85:183-191. doi: 10.1080/02772 240410001665418

American Standards Testing Materials (ASTM). 2006. Standard guide for conducting 10-days static sediment toxicity test with marine and estuarine amphipods. In Annual Bookof ASTM Standards, Water and Environmenral Technology. American Society for Testing Materials, Philadelphia:1367-1392.

Angel, B.M., S.L. Simpson \& D.F. Jolley. 2010. Toxicity to Melita plumulosa from intermittent and continuous exposures to dissolved copper. Environ. Toxicol. Chem. 29:2823-2830. doi: 10.1002/etc.347

Batley G.E. \& S.L. Simson. 2009. Development of guidelines for ammonia in estuarine and marine water systems. Mar. Pollut. Bull. 58: 1472-1476.

Boardman, G.D., S.M. Starbuck, D.B. Hudgins, X. Li \& D.D. Kuhn. 2004. Toxicity of Ammonia to Three Marine Fish andThree Marine Invertebrates. Environ Toxicol. 19:134-142.

Burgess, R.M., K.A. Schweitzer, R.A. McKinney \& D. Phelps. 1993. Contaminated marine sediments: water column and interstitial toxic effects. Environ. Toxicol. Chem. 12:127-138. doi: 10.1002/etc.5620120114

DeWitt, T.H., R.C. Swartz \& J.O. Lamberson. 1989. Measuringthe acute toxicity of estuarine sediments. Environ. Toxicol. Chem. 8:10351048. doi: 10.1002/etc.5620081109

Ferretti, J.A., D.F. Calesso, \& T.R. Hermon. 2000. Evaluation of methods to remove ammonia interference in marine sediment toxicity tests. Environ. Toxicol. Chemistry. 19:1935-1941. doi: 10.1002/etc.5620190801

Gorbi, G., M. Invidia, F. Savorelli, O. Faraponova, E. Giacco, M. Cigar, I. Buttino, T. Leoni \& E. Prato. 2012. Standardized methods for acute and semichronic toxicity tests with the copepod acartia tonsa. Environ. Toxicol. Chem. 31:2023-2028. doi: 10.1002/etc.1909

Hamilton, M. A., R.C. Russo \& R. V. Thurston. 1977. Trimmed Spearman-Karber method for estimating median lethal concentrations in toxicity bioassays. Environ. Sci. Technol. 11: 714-719. doi: 10.1021/es60130a004

Hindarti, D., Z. Arifin, T. Prartono, E. Riani \& H.S. Sanusi. 2015. Survival of tropical benthic 
amphipod Grandidierella bonnieroides Stephenson 1948 on differenct sediment particle size: Implications for ecotoxicological testing. Int. J. Mar. Sci. 5(34):1-6. doi: 10.5376 /ijms.2015.05.0034

Ingersoll, C.G., J.M. Kunz, J.P. Hughes, N. Wang, D.S. Ireland, D.R. Mount, J.R. Hocket, \& T.W. Valenti. 2015. Relative sensitivity of an amphipod Hyalella azteca, a midge Chironomus dilutus, and a unionid mussel Lampsilis siliquoidea to a toxic sediment. Environ. Toxicol. Chem. 34:1134-1144. doi: 10.1002/etc.2909

Kohn, N.P., J.Q. Word, D.K. Niyogi, L.T. Ross, T. Dillon \& D.W. Moore. 1994. Acute toxicity of ammonia to four species of marine amphipod. Mar. Environ. Res. 38:1-15. doi: 10.1016/01441136(94)90042-6

Lee, J.S., K.T. Lee \& G. S. Park, 2005a. Acute toxicity of heavy metals, tributyltin, ammonia and polycyclic aromatic hydrocarbons to benthic amphipod Grandidierella japonica. Ocean Sci. J. 40:61-66. doi : 10.1007/BF03028586

Lee J.S., K.T. Lee, D.H. Kim, Kim C.K, J.H. Lee, K.H. Park K.H. \& G.S. Park. 2005b. Application of indigenous benthic amphipods as sediment toxicity testing organisms. Ocean Sci. J. 40:1724. doi: 10.1007/BF03023462

Mehler, W.T., J.D. Maul, J. You \& M.J. Lydy. 2010. Identifying the causes of sediment-associated contamination in the illinoisriver (usa) using a whole-sediment toxicity identification evaluation. Environ. Toxicol. Chem. 29:158167. doi: 10.1002/etc.20

Moore, D.W., T. S. Bridges, B.R. Gray \& B.M. Duke. 1997. Risk of ammonia toxicity during sediment bioassay with the estuarine amphipod Leptocheirus plumulosus. Environ. Toxicol. Chem., 16(5):1020-1027. doi: 10.10 02/etc.5620160523

Newton, T.J. \& M. Bartsch. 2007. Lethal and sublethal effects of ammonia to juvenile LampsilisMussels (unionidae) in sediment and water-only exposures. Environ. Toxicol. Chem. 26(10):2057-2065. doi: 10.1897/06-245R.1

Russo R.C. 1985. Ammonia, nitrite and nitrate. GM Rand and SR Petrocelli (Eds.). Fundamentals of aquatic toxicology. Hemisphere Publ., USA, pp. $455-474$
Schubauer-Berigan, M.K., P. Monson, C. West \& G. Ankley. 1995. Influence of $\mathrm{pH}$ on the toxicity of ammonia to Chironomus tentans and Lumbriculus variegatus. Environ.Toxicol.Chem., 14(4):713-717. doi: 10.1002/etc.562014 04 19

SVL Analytical, 2010, http://www.svl.net.2010/09/ unionized-amonia-calculator

Swartz, R.C., F.A. Cole, Schults \& W.A. DeBen. 1986. Ecological changes in theSouthern California Bight near a large sewage outfall: benthic conditions in 1980 and 1983. Mar. Ecol. Prog. Ser. 31:1-13.

US EPA (United States Environmental Protection Agency) 1994. Methods for assessing the toxicity of sediment-associated contaminants with estuarine and marine amphipods. U.S. Environment Protection Agency, Report EPA 600/R - 94/025. (Narragansett, Rhode Island 02882, USA, June 1994).

US EPA (United States Environmental Protection Agency) 1999. Ambient water quality criteria for ammonia. EPA 882-R-99- 014. US Environmental Protection Agency Office of Water, Washington, DC, USA.

US EPA (United States Environmental Protection Agency) 2001a. Method for Assessing the Chronic Toxicity of Marine and Estuarine Sediment-associated Contaminants with the Amphipod Leptocheirus plumulosus. EPA 600/R-01/020. 120 pp.

US EPA (United States Environmental Protection Agency) 2001b. Update of Ambient Water Quality Criteria for Cadmium. EPA-822-R-01001, US Environmental Protection Agency Office of Water, Washington, DC, USA

Van Sprang, P. \& C.R. Janssen. 1997. Identification and confirmation of ammonia toxicity in contaminated sediments using a modified toxicity identifiction evaluation approach. Environ. Toxicol. Chem. 16:2501-2507. doi: 10.1002/etc.5620161210

Wang, N., R.A. Consbrock, C.G. Ingersoll \& C. Barnhart. 2011. Evaluation of influence of sediment on the sensitivity of a unionid mussel (Lampilis siliquoidea) to ammonia in 28-day water exposures. Environ. Tox. Chem. 30: 2270-2276. doi: 10.1002/etc.616 
Whiteman, F. W., M.D. Kahl, D.M. Rau, M.D. Balcer \& G. T. Ankley. 1996. Evaluation of interstitial water as a route of exposure for ammonia in sediment tests with benthic macroinvertebrates. Environ. Tox. Chem. 15:794-801. doi: 10.1002/etc.5620150527 